\title{
Nature-inspired calcium phosphate coatings: present status and novel advances in the science of mimicry
}

\author{
A.L. Oliveira ${ }^{\text {a,b }}$, J.F. Mano ${ }^{\text {a,b }}$, R.L. Reis ${ }^{a, b, *}$ \\ a 3B's Research Group-Biomaterials, Biodegradables \& Biomimetics, University of Minho, Campus de Gualtar, 4710-057 Braga, Portugal \\ b Department of Polymer Engineering, University of Minho, Campus de Azurém, 4800-058 Guimarães, Portugal
}

Received 27 October 2003; accepted 31 October 2003

\begin{abstract}
There has been a growing awareness in materials science that the adaptation of nature biological processes can lead to significant progresses in the controlled fabrication of advanced materials for an all range of applications. To learn from, understand and apply these natural processes for producing calcium phosphate coatings that are biologically similar to bone apatite, mimicking its properties, has driven the attention of many researchers in recent years. This article reviews the most relevant advances in this emerging research field, pointing out several approaches being introduced and explored by distinct laboratories.
\end{abstract}

(C) 2003 Published by Elsevier Ltd.

\section{Introduction}

The present overview is intended to draw the readers' attention to the processes by which mineralized tissues are formed. The main aim is to provide useful information that can be applied as a source of inspiration for the development of new materials to be used in the biomedical field, particularly in bone-related applications. That is the rational for searching materials capable of mimicking the living tissues, i.e. the so-called biomimetic materials. In the case of bone replacement innovative ideas can be generated by means of studying the mineralized tissues found in Nature. The main research question in this field is: if the basic strategies by which living organisms produce mineralized tissues are understood, how might these principles be exploited for the development of new biomaterials? If biomimetic is interpreted as the reproduction of the entire sequence of biomineralization steps, it is then clear that any developed process would be extremely complex and would lead to unbearable costs. Moreover, it must be understood that is not possible to compete with thousands of

\footnotetext{
${ }^{*}$ Corresponding author. Address: Department of Polymer Engineering, University of Minho, Campus de Azurém, 4800-058 Guimarães, Portugal. Tel.: +351-253-604781/640782; fax: +351-253604492 .

E-mail address: rgreis@dep.uminho.pt (R.L. Reis).
}

million years of Nature's "research work"! A less literal use of the term biomimetic should then be applied. If a materials scientist can be inspired by a biological prototype to apply its principles to his research area, then a biomimetic result can be achieved. At the moment lessons from Nature are already being applied, leading to the creation of new biomaterials and methodologies, particularly those that are able to stimulate the tissues for eliciting specific responses at the interface with bone, in order to create a continuous transition from tissue to implant material. However there is still much to be studied and understood and the potential of biomimetics is still not really being put to work for engineering better biomedical systems. This review will discuss some lessons that can be obtained from Nature in order to improve bone-related implants and tissue engineering scaffolds by means of developing adequate biomimetic coating routes.

\section{Biomineralized structures: lessons from nature}

The traditional design of materials has been mainly motivated by basic concepts of Chemistry (choice of the type of material to be used-polymer, ceramic, metal, composite...; surface modifications; inclusion of special chemical groups), along with some input from physic (e.g. for electronic, electrical or optical applications) and engineering (processing and macrostructure design, that 
should include internal size control from nano- to macro-dimensions). Nevertheless, there has been an increasing interest in the study of biological systems that could inspire the conception of new and better materials with tailored/engineered properties. The hypothesis is that materials in Nature should have been continuously improving their performance under evolutionary pressures in both design and function, since the appearance of life on Earth. As a trivial and straightforward example, Aramides, such as $\mathrm{Kevlar}^{\circledR}$, are synthetic polyamides that are the gold standard in the production of high strength and modulus and low weight polymeric fibres for a variety of structural applications (ballistic and defence protection, high performance cables and ropes...). Their processing involves the use of sulphuric acid as the solvent and both high temperatures and pressures. It is interesting to compare such processing conditions with those of natural spider silk that is produced under aqueous solution $(\mathrm{pH}$ near 7$)$ at both atmospheric temperature and pressure, and exhibits an even higher toughness than $\operatorname{Kevlar}^{\circledR}$ [1]. In the particular case of biological hard tissues (such as bones, shells, teeth or spicules), there is the formation of hierarchical structures with complex architecture from the nanometre to the millimetre scales, combining minerals, structural biological polymers (proteins and polysaccharides) and lipids [2,3]; under the correct genetic control of the shape and pattern in time and space, the biocomposites are produced with minimum energy costs using an environmentally friendly biomineralization synthesis pathway. The resulting tissue tends to optimise its function, and often its multifunctions, preferentially minimizing the amount of materials required. Moreover, biological materials are also "smart" as they adapt internally to external events, which includes their "selfrepairing" ability. Biomineralized structures exist in all five kingdoms of organisms and the functions are very diverse, including mainly structural and load-bearing purposes (e.g. bone, mollusc shells, teeth) but also sound reception, optical, magnetic and gravity sensing and temporary storage of ions or rejection of wastes [2,3]. In terms of length scale we can find structures that can go from single $\sim 50 \mathrm{~nm}$ magnetite crystals, acting as magnetic domains in magnetotactic bacteria monitoring the Earth's magnetic field [4], up to the huge molars of elephants made of ivory [5]. Such systems also cover a considerable range of organic component weight fraction that can go from $0.1 \%$ in cross lamellar shells and echinoderm calcite up to about $20 \%$ in bone [6]. One also finds a variety of morphological diversity and complexity in biological minerals (often exhibiting no resemblance to their inorganic counterparts), even for a common function [7]. And this is built using a limited number of mineral possibilities (including amorphous minerals and both inorganic and organic crystals $[6,8]$ ), where only a few minerals are the main component of endo- and exo-skeletons [9]. It should also be noted that none of such minerals have, by themselves, particular outstanding characteristics - again, their success is the way they are assembled together with the organic phase. Among such biogenic minerals, calcium is present in some $50 \%$ of them [2]. This reflects both the natural abundance of this metal in the oceans and its importance as the cell's messenger (due to its efficient transport throughout the cell by membrane pumps) [2]. The two major calcium compounds that are found are calcium carbonate, appearing mainly in shells of marine creatures and eggshells, and calcium phosphate, e.g. in bone and dentin in vertebrates. In the former case, three main polymorphs are found (calcite, aragonite and vaterite), and among them, different shapes may be found $[2,10]$. An interesting study by Chateigner et al. [8] tried to systematise the great variety of crystallographic textures in shells from monoplacophoras, bivalves, cephalopods and gastropods. A good example occurs in shells of bivalves that exhibit two layers of differently shaped aragonite crystals, neither of them being similar to the crystals formed inorganically [2]. This is due to the precise calcium-binding sites that are dictated by the structure of the nucleating proteins (negatively charged, interacting electrostatically with the calcium ions), which are glycoproteins rich in aspartic acid, possibly with a $\beta$-sheet structure $[2,10]$. Such stereochemical selfassembled templates will control both the nucleation and the growth of the inorganic precipitation reactions, determining the final size, shape and orientation of the formed crystalline structure [11]. These "control macromolecules" [10] are usually the minor macromolecular component of a biological material, being intimately attached to the mineral phase; they are, in fact, difficult to extract or degrade without dissolving the mineral [10]. It is interesting to notice in this context that such acidic soluble proteins inhibit crystallization in solution, as rigidity and regularity is then lost. This is related with the way Nature controls the biomineralization process: minerals formed in organisms require a precise isolation in space [2], either delineated by macromolecular matrix frameworks (providing a 3D matrix for crystal formation and a substrate for the interaction between the control macromolecules and the mineral phase [10]), or else by confinement from cell membranes or vesicles $[2,3]$. These evidences suggest that analogous synthetic templates could be used in the production of tailor-made mineral structures. As described by Green et al. [12], surfactant micelles, lipid microstructures, and stacked bacterial filaments have been proposed to control precipitation and growth of inorganic minerals such as silica and iron oxides. In that particular work, an analysis is made where chemical and biological concepts of self-assembling and self-organization found in natural porous skeletons can be used in the development of bone-analogue structures for hard tissue engineering 
[12]. It should also be noticed in this context that apparently different biomineralized structures can exhibit physiological compatibility [13]. A good example is the bone-conductive properties of shells. For instance, implantation of nacre powder in jawbone promotes osteoblasts activation and bone formation, with no inflammatory response [13]. However, no definitive explanation for this behaviour is really known, although the authors claim [13], for example, a matching between the nacre and bone organic matrices. These facts can be also in accordance with the ability of gastropod nacre to be converted hydrothermally into hydroxyapatite (the inorganic-calcium phosphate - component of bone) [14].

\section{Bone as a material}

As this review focuses on biomimetic mineralization, mainly aiming to find better ways for increasing the biocompatibility and the performance of biomaterials used in bone related applications (filling bone defects, fixation, bone tissue engineering scaffolding, etc.), one should look in more detail at relevant aspects of the structure and mineralization in bone. Properties of bone have been widely studied. It has been known for a long time that this material has multi-functional properties, which include structural support, protection and storage of healing cells, and mineral ion homeostasis [15]. The "material bone" should be understood herein as a family of materials built up of mineralised collagen fibrils. The structure of bone and its relation with the mechanical properties are very well discussed elsewhere $[15,16]$. Collagen is the "framework macromolecule" in bone, in contrast with the Gly- and Ala-rich proteins in mollusc shells [10]. Although many more protein exist in bone (e.g. phosphoproteins, that have an important role in the biomineralization process), collagen is the main component of the $3 \mathrm{D}$ matrix into which (or onto which) the hydroxylapatite $\left(\mathrm{Ca}_{10}\left(\mathrm{PO}_{4}\right)_{6}(\mathrm{OH})_{2}\right)$ is deposited, in the form of thin plates with $50 \times 25 \mathrm{~nm}$ of length and width and with $2-3 \mathrm{~nm}$ thickness $[16,17]$. In the lowest level of bone organization, type-I collagen is self-assembled into fibrils. First collagen peptides are assembled into the cells; however, further assembly into bundles occurs in the extracellular medium [18]. Collagen molecules in fibrils appear with $1.5 \mathrm{~nm}$ thick (thickness of one triple-helical molecule), $300 \mathrm{~nm}$ length and with $40 \mathrm{~nm}$ gaps or holes between the ends [16]. The apatite crystals are nucleated at specific regions on or within the collagen fibrils [19]. They grow in the hole zones (channels) and in later stages they penetrate into the overlap zones that exists between neighbouring collagen molecules $[16,20]$. This compresses the triplehelical collagen framework, diminishing the average distance between collagen molecules from 1.5 to $1.2 \mathrm{~nm}$ with crystal growth [2]. Such highly anisotropic fibrils are then arranged in higher order organizations. In lamellar bone, there are parallel arrays of fibrils, with crystals aligned (sub-layers). The consecutive sub-layers rotate though the lamellar plane by an average of $30^{\circ}$, forming a so-called plywood-like structure [12]. As each lamella is composed of five sub-layers, the total rotation is $150^{\circ}$, thus forming an asymmetric structure. Moreover, the collagen fibril bundles rotate around their axis within the five sub-layers. These two events reduce strongly the macroscopic anisotropy of bone. This tendency, that is found in lamellar bone, seems to be general in Nature. Weiner et al. [6] presented several examples in which organisms use different strategies to reduce anisotropy in biomineralized structures. Lessons such as these may be useful to design better materials that will substitute or be in contact with living tissues. For instance, biomimetic coatings have been developed in order to be functionally efficient, being produced using an environmental benign process [21]. This leads to new technological materials that can be used in bone and cartilage repair. Up to now, as it will be seen in this review, we are still in the stage of engineering the substrate surfaces using more or less complex Chemical and Physical methods. For example, important contributions have been resulting from the works of Mann et al. $[22,23]$, that achieved the orientation of the crystallisation of calcium carbonate from homocharge cation layers in supersaturated $\mathrm{CaCO}_{3}$ solutions. Also, calcite nucleation could be obtained in polystyrene substrates decorated with sulfonate and carboxylate moieties [24], which corresponds to a nice model of the mineralization occurring in molluscs [11]. A nucleating matrix isolated from Abalone shells also induced the formation of aragonite, when proteins also extracted from Abalone shell were added to it [25]. Despite such nice results, the nucleation mechanism involved in vitro (and of course in vivo) is far from being understood.

It will then be always very difficult to mimic exactly the calcification process that occurs in bone. This is further complicated as all mineralization processes are ultimately controlled through the cells directly associated to the tissue formation [26]. Nevertheless, the great understanding that currently exists of bone biology may provide key concepts that may be adapted within a synthetic context. As done with the calcium carbonate mineralization studies, a step further would be to control the precipitation of the minerals using templates of biomineralization proteins for the control of crystal organization and properties. This would allow enhancement of the biological activity with the bone/ cartilage mineral structure for bone cell adhesion, alignment, spreading and differentiation. This is of course not an easy task, as the extraction of such macromolecules directly from the natural composites involves complex procedures such as protein isolation and purification, amino acid analysis and sequencing [27]; 
the use of similar existing proteins is also inefficient as the binding to the inorganic surfaces is non-specific. As commented by Sarikaya [27], a better solution would be the molecular design of recombinant proteins via genetic engineering techniques. As in other biomimetic strategies, the conventional engineering and chemical approach must gradually be substituted by endeavours in areas such as genetics, proteonics and nano-technologies, i.e., to learn how to use the same tools of the living organisms. This would include the mastering of molecular and supra-molecular organization (self-assembling). This area has having an increasing interest in many fields [28-30], and includes, for example, the production of electronic devices [29] or micro-patterning of single crystals [30] using biomimetic approaches.

Besides the surface composition (that will dictate the chemical environment) the osteogenic process of bone cells will also depend on the roughness and topography of the surface. An important issue for the case of 3D porous structures (e.g. in scaffolds for tissue engineering) is also their meso/macro-organization. As referred by Green et al. [12] pore diameters between 15 and $50 \mu \mathrm{m}$ stimulate fibrovascular growth, between 50 and $150 \mu \mathrm{m}$ stimulate osteoid formation and in the range of 150-500 $\mu \mathrm{m}$ lead directly to mineralised bone. Other authors [3133] indicate different figures for these porosities. Despite such insights, the ideal porous structure which would maximise bone growth, in terms of pore dimension distribution and interconnectivity is still unknown. In such complex structures it is often not straightforward to engineer uniform coatings for bone compatibility enhancement. In this review some biomimetic coating procedures that have potential to surpass this shortcoming will be presented and discussed in detail.

\section{Ca-P coatings: present status}

When considering an ideal material to replace and mimic bone, synthetic calcium phosphates (currently designated as Ca-Ps or "apatites") can be an obvious answer, since they can replicate the structure and composition of bone mineral - hydroxylapatite (HA) - in a reproducible way. Unsurprisingly, $\mathrm{Ca}-\mathrm{Ps}$ have a biocompatible behaviour with most of the cell types such as osteoblasts, osteoclasts, fibroblasts, and periodontal ligament cells, being found in the calcified tissues [34-37]. Furthermore, Ca-Ps disclose osteoconductive properties allowing for the formation of bone on its surface by attachment, migration, proliferation, and differentiation of bone-forming cells [38,39]. However, despite having a similar composition and chemistry to that of human bone, the mechanical properties of $\mathrm{Ca}-\mathrm{Ps}$ are far from being close to those of human bone, which limits their use for load-bearing applications. In fact $\mathrm{Ca}-\mathrm{Ps}$ are too stiff and often very brittle.
Today's solutions of materials for bone replacement are still far from being ideal. In fact, metallic implants are still the first choice for load-bearing applications, despite all the problems associated with stress-shielding [40] and long term application [41]. Although progress is being made at this very moment, the right balance between surface and bulk properties of an orthopaedic material is still to be achieved. At the present, one of the most interesting solutions to this problem is to use $\mathrm{Ca}-\mathrm{Ps}$ as a coating on the surface of load-bearing implants [38,42-45]. Therefore, and in spite of their low mechanical properties, these types of coatings have great potential for bone fixation applications, or to be used on scaffolds for tissue engineering. In fact, these coatings can be tailored in terms of chemical composition, crystallinity and resorbability $[46,47]$ and also can be loaded with osteogenic biological molecules [48-50] or serve as beds for the seeding of living cells that will stimulate bone formation [45,51].

At the present the commercially available methods to produce such $\mathrm{Ca}-\mathrm{P}$ coatings are in fact just a few and still the same as proposed a decade ago, having several disadvantages like difficulties in controlling the calcium-phosphate (Ca-P) layer composition, resorbability, weak adhesion to the substrates, the use of high temperatures or the costs involved in the process. Moreover, these methodologies are not effective in coating complex shapes. On the other hand new challenges are now being raised: to coat the interior of a porous material would be highly interesting when thinking about the immerging concepts linked to tissue engineering. These coatings would facilitate the cell attachment and proliferation in the interior of a scaffold, which will eventually and ideally be followed by the process of vascularization. For the last 30 years there has been a great amount of research aiming at the development of effective coating methodologies. But, if so, should not we be more ahead? Why has this particular area progressed so little? In our opinion, there is more than one straight answer...

The plasma-spraying technique is, to date, the major commercially available method, used for coating $\mathrm{Ca}-\mathrm{P}$ on metallic implants [52-55]. The first coated implant was commercialized in 1980 by Valen for dental applications. It is amazing to imagine that the same technique is still being used, if we think how much we have progressed from then (how would our lives be if we were still using computers from that time?!). But the fact is that the reproducibility and economic efficiency of the process are clear advantages that can not be disregarded, hence its popularity goes from 20 years ago to the present day [53,54]. However, this method presents some crucial drawbacks affecting the long-term performance and lifetime of the implant. The most significant are the poor coating-substrate adhesion [54] and lack of uniformity of the coating in terms of morphology and crystallinity 
$[55,56]$. Since plasma-spraying is a high-temperature and line-of-sight process, there are also some aspects that were not solved yet, such as the deteriorating effect of intense heat on substrates, non-uniformity in coating density, wide range of band strength and the unavoidable limitations when trying to coat implant devices with complex shapes [53-56]. Other studied approaches have been sputter coating techniques that have been shown to be able to increase the bond strength between the coating and the substrates [57-59]. However, the inherent drawbacks are that the deposition and the process itself are very slow, the coatings quite thin, or their cohesion not adequate. A collection of other methodologies have been proposed such as: dip coating sintering [60], chemical vapour deposition [61,62], sol-gel deposition [63-65], ion implanting [66] laser deposition [67-69], laser cladding [70] and electrochemical processes like electrophoretic deposition [71], electrocrystallization [72,73], anode oxidation [74], or electroless coatings [75] to name just a few examples. Despite all of the investigations carried out, the produced coatings can suffer from at least one of the following problems [42]: lack of coating adherence to the substrate, thickness nonuniformity, poor structure integrity, non-stoichiometric composition of the coatings and limitations on choosing the type of substrate due to high temperatures of the process. In fact, each of the above mentioned techniques has its own technical limitations, and so far, an optimal technique for producing physiologically stable and interfacially adherent apatite coatings is yet to be developed. Thus, there is a demand to develop innovative methods able to face new challenges such as a technique when engineering bone implants or designing tissue engineering scaffolds to form an apatite layer (with properties similar to those of bone calcium-phosphates on the surface of new emerging materials) on various complex shaped materials, so that both biocompatibility as well as bioactivity are enhanced within this context a very attractive idea is to develop processes in which biologically active molecules, such as osteogenic agents and growth factors, could be incorporated in the coating.

\section{The biomimetic approach applied to produce $\mathbf{C a}-\mathbf{P}$ coatings}

As described above, $\mathrm{Ca}-\mathrm{P}$ minerals found in natural hard tissues are produced spontaneously in a physiological environment at low temperatures from moderately supersaturated mineralizing solutions [76]. To learn, understand and apply these natural processes for producing $\mathrm{Ca}-\mathrm{P}$ coatings biologically identical to bone apatite has been the focus of the attention of many researchers in recent years [77-81]. The so-called biomimetic preparation of calcium phosphate coatings on implant materials has then emerged as a new concept, and several methodologies have been proposed. This type of approach is particularly suitable to coat polymeric materials [77,81-87], as it can be carried out at low temperature reaction conditions.

A calcium phosphate coating was first grown on a substrate by a biomimetic process by Kokubo et al. in 1990 [81]. For this purpose, a bioactive $\mathrm{CaO}-\mathrm{SiO}_{2}$-based glass was used in the form of particles that were set in contact with the substrates to induce apatite nucleation on their surface in a simulated body fluid (SBF) with ion concentrations nearly equal to those of the human blood plasma and at body temperature. This solution was developed also in 1990 by the same author [21]. The mechanism of apatite formation is well known: the silanol groups $(\mathrm{Si}-\mathrm{OH})$ contained in the silicate ions are released from the bioactive glass and adsorbed on the substrate surface to induce the formation of a $\mathrm{Ca}-\mathrm{P}$ layer $[81,88,89]$. Another very important aspect of this methodology is that it is highly dependent on the conditions of SFB immersion. In fact, parameters like time, temperature, agitation, renovation or ion concentration of the SBF solution are extremely important in tailoring the apatite formed. For example, Kim et al. [90] have reported that different apatite layers can be produced on polyethylene terephthalate (PET) substrates in solutions where the ion concentrations were changed from 0.75 to 2.00 times those of SBF. Increasing the ionic activity product then resulted in lower $\mathrm{Ca} / \mathrm{P}$ ratios of the apatites. The same author [91] has also reported that by increasing the carbonate ion content, apatites with composition and structure nearly identical to those of bone carbonated apatite could be produced. In fact, SBF solution is known to be deficient in relation to the $\mathrm{HCO}^{3-}$ content, when comparing to the human blood plasma $[21,91]$. Therefore, this group has now proposed a new revised SBF (R-SBF) with an ion composition closer to the human blood plasma (higher amounts of $\mathrm{HCO}^{3-}$ ), to replace conventional SBF [92]. Although this new solution has already been proposed 3 years ago, the original SBF is still the one being widely used by different groups all over the world [84,93-100].

There is a quite considerable amount of published work using other different biomimetic routes for the formation of apatite layers on the surface of different materials $[82,85,95,98,99,101-103]$. Some of them are based on surface modifications, by chemical or physical means that are claimed $[85,95,98]$, to induce direct bioactivity in the surface of the materials. Other methodologies use nucleating agents to induce the formation of the bioactive layer [77,82]. In both cases the basic principle is the formation at the surface (either by chemical bond or adsorption) of certain functional groups that seem to be favourable for inducing apatite formation. The works developed by Kobubo and his group $[96,104]$ provide researchers with information that helps to understand better what would be the ideal 
surface chemistry for promoting apatite formation. They found that not only $\mathrm{Si}-\mathrm{OH}$ but other negatively charged groups at physiological conditions are favourable for apatite formation, for example $\mathrm{Ti}-\mathrm{OH}, \mathrm{Zr}-\mathrm{OH}$, $\mathrm{Ta}-\mathrm{OH}$, and $\mathrm{Nb}-\mathrm{OH}$ groups [96]. In contrast, positively charged $\mathrm{Al}-\mathrm{OH}$ groups are not effective. However, besides the charge, the spatial arrangement of the groups also play a very important role since, for example, not all titania gel structures lead to the formation of $\mathrm{Ti}-\mathrm{OH}$ groups with an ability to form apatite [105].

In another very interesting study carried out by by Tanashi et al. [46] the ability of various surface functional groups to nucleate a $\mathrm{Ca}-\mathrm{P}$ layer after immersion in SBF was evaluated on a self-assembled monolayer (SAM) of alkanethiols over a gold substrate. They were able to establish a hierarchy of functional groups. The most potent nucleating group was $-\mathrm{PO}_{4} \mathrm{H}_{2}$ followed by $-\mathrm{COOH}$. The groups $-\mathrm{CONH}_{2},-\mathrm{OH}$ and $-\mathrm{NH}_{2}$ were considered as groups with a weaker nucleating ability. Finally $-\mathrm{CH}_{3}$ was found to have no ability to promote apatite formation in the presence of the ions from SBF. Only the first two groups were charged negatively which explains their ability to form a $\mathrm{Ca}-\mathrm{P}$ layer. These different studies demonstrate that there is more than one approach for inducing the formation of a $\mathrm{Ca}-\mathrm{P}$ on a surface. In fact, each coating methodology should be designed while considering the desired substrate in terms of its chemistry, structure and surface morphology. The authors of this review really believe that different biomimetic routes should be applied to different materials/substrates.

\section{Biomimetic $\mathrm{Ca}-\mathrm{P}$ coatings on biodegradable polymers and tissue engineering scaffolds}

Over the last few years the 3B's Research Group at the University of Minho has been giving special attention to the biomimetic preparation of $\mathrm{Ca}-\mathrm{P}$ coatings, particularly to be applied on the surface of biodegradable polymers. Starch-based biodegradable polymers are particularly interesting for bone replacement [106-114]. Besides being biodegradable, inexpensive (when compared to other biodegradable polymers) and available in large quantities [115-117], these polymers can be converted into complex geometries that exhibit interesting mechanical properties, by using standard processing routes for synthetic polymers $[106,110,118-120]$ or by means of using distinct innovative methodologies $[109,112,121,122]$. Furthermore, in addition to their processing versatility, they exhibit a biocompatible behaviour, already demonstrated on different in vitro $[111,123,124]$ and in vivo [125] studies. To induce a bioactive behaviour on the surface of these biodegradable polymers, via different surface modifications and biomimetic routes, has been one of the major goals of the works of Reis and co-workers, even with all the difficulties arising from the $\mathrm{pH}$ changes and continuous degradation of the polymeric surfaces.

The first biomimetic studies have used an adaptation of the standard biomimetic methodology [108] in which the samples were rolled in a bed of wet bioactive glass particles before immersion in an SBF solution. The methodology was effective in coating different types of polymers and shapes, such as a high molecular polyethylene, a biodegradable starch poly(ethylene vinyl alcohol) blend (SEVA-C) and a polyurethane foam. Nevertheless, problems associated with a lack of coating adhesion were observed. Therefore, different surface modifications were then experimented, some of which have already led to some interesting results. Surface treatments like potassium hydroxide $(\mathrm{KOH})$, UV radiation and overexposure to ethylene oxide sterilization, on SEVA-C substrates, applied before the biomimetic process have proved to be very effective in increasing the adhesion to the substrate and reducing the incubation periods for apatite formation [78]. In later studies, there was a need to develop alternative biomimetic methodologies in order to better control the nucleation and growing of bioactive $\mathrm{Ca}-\mathrm{P}$ layers on the surface of our materials. Since starch based polymers have a high swelling ability, they are able to uptake ions from the surrounding medium, when immersed in SBF. Based on this idea new biomimetic methodologies were developed through different approaches like: "impregnation" with a sodium silicate gel $[51,84]$, pre-coating with a calcium silicate layer [126] or incubation in several supersaturated salt solutions $\left(\mathrm{CaCl}_{2}, \mathrm{KCl}\right.$ and $\left.\mathrm{MgCl}_{2}\right)$ [127]. These surface treatments were performed prior to immersion in a simulated body fluid (SBF), in order to generate nucleating sites for the formation of the apatite layers. The developed methodologies aimed at: (i) the reduction of the incubation periods for apatite formation; (ii) the improvement of the adhesion strength between the coating and substrate; (iii) the production of $\mathrm{Ca}-\mathrm{P}$ layers with different (tailored) $\mathrm{Ca}-\mathrm{P}$ ratios; (iv) the coating of the inside of pores in porous $3 \mathrm{D}$ architectures to be used on tissue replacement and as tissue engineering scaffolds. Silicate-based methodologies in particular have been demonstrated to be extremely effective in coating porous scaffolds with different morphologies. Since gels were used, it was possible to cover inside the cell walls of different porous structures $[84,126]$. Therefore, one of the most promising aspects of the developed biomimetic methodologies is that they can be suitable to produce apatite coatings onto complex-shaped materials. In case of the sodium silicate gel methodology, the influence of the ion concentration of the SBF solution was also studied, and it was possible to observe that when increasing the ionic product of the solution, there was a slight increase on the apatite crystallinity which had a positive effect on cell adhesion and proliferation kinetics [51,84]. 
At the present Reis and co-workers are starting to use these methodologies for designing systems for the release of bioactive molecules at the coating level. As a result, there are new opportunities for applying this type of coatings in the field of tissue engineering, as a way to enhance the cell adhesion and proliferation and the extra-cellular matrix production. Some possibilities are presently being considered, based on the incorporation of osteogenic biological molecules in some biomimetic coatings [50]. Due to the physiological coating conditions used, it is expected that, when applying these methodologies, the bioactive factors can preserve their biological activities. Therefore, considering the slow, but definite degradation of $\mathrm{Ca}-\mathrm{Ps}$ as well as their high hydrophilicity [128], they may be very suitable to serve as carriers for these molecules. The options for creating a delivery system in these coatings are numerous. For example, certain molecules like protein growth factors can regulate various cell functions such as growth, differentiation, secretion, and apoptosis [129]. The authors do believe that producing these hybrid coatings on 3D biodegradable porous scaffolds, with adequate resorbability, can represent a very promising opportunity for introducing coated biodegradable scaffolds in the field of tissue engineering. Although in this review we have been mainly discussing biomimetic coating methodologies applied to biodegradable starch based polymers, other authors have also been able to coat by biomimetic routes several other polymers. Some examples are coatings produced on cotton [95], silk [103], chitosan [130] and collagen [131]. Du et al. [132] presented a 1day one-step incubation method to obtain either amorphous or bone-like apatitic calcium phosphate coating on dense plates or three-dimensional porous blocks of PEO/PBT $\left(\right.$ Polyactive $^{\circledR}$ ) 1000/70/30. However this was only possible by means of bubbling $\mathrm{CO}_{2}$ gas in a derived concentrated simulated body fluid. Bone-like apatite coating on poly(L-lactic acid) (PLLA) fibres was also obtained by Yuan et al. [133] by immersing the fibres in a modified simulated body fluid (SBF) at $37^{\circ} \mathrm{C}$ and $\mathrm{pH}$ 7.3 after hydrolysis of the fibres in water.

\section{Conclusions}

Novel biomimetic coating routes have been developed in order to produce $\mathrm{Ca}-\mathrm{P}$ layers on orthopaedic implants and tissue engineering scaffolds. There is already available in the literature a range of possible biomimetic coating routes that researchers and industry can choose from. However, these methodologies are still to be introduced in industrial plants and then in clinical practice. It is, nevertheless, the belief of the authors that by means of continuing to learn from Nature, and by incorporating bioactive agents into the coatings, it will be possible to use this coated systems in the clinical practice. Many research groups and already some major companies are pursuing that demanding goal. Nature will continue to lead us all!

\section{References}

[1] Guinea GV, Elices M, Perez-Rigueiro J, Plaza G. Self-tightening of spider silk fibers induced by moisture. Polymer 2003;44:5785-8.

[2] Addadi L, Weiner S. Control and design principles in biological mineralization. Angew Chem Int Ed 1992;31:153-69.

[3] Mann S. Biomineralization, principles and concepts in bioinorganic materials chemistry. Oxford: Oxford University Press; 2001.

[4] Webb J, Macey DJ, Chua-anusorn W, St Pierre TG, Brooker LR, Rahman I, et al. Iron biominerals in medicine and the environment. Coordin Chem Rev 1999;192:1199-215.

[5] Su XW, Cui FZ. Hierarchical structure of ivory: from nanometer to centimeter. Mater Sci Eng C-Bio S 1999;7:19-29.

[6] Weiner S, Addadi L, Wagner HD. Materials design in biology. Mater Sci Eng C-Bio S 2000;11:1-8.

[7] Mann S. The chemistry of form. Angew Chem Int Ed 2000;39:3393-406.

[8] Chateigner D, Hedegaard C, Wenke HR. Mollusc shell microstructures and crystallographic textures. J Struct Geol 2000;22:1723-35.

[9] Lowenstam HA, Weiner S. On biomineralization. New York: Oxford University Press; 1989.

[10] Weiner S, Addadi L. Design strategies in mineralized biological materials. J Mater Chem 1997;7:689-702.

[11] Addadi L, Weiner S. Interactions between acidic proteins and crystals stereochemical requirements in biomineralization. Proc Natl Acad Sci USA 1985;82:4110-4.

[12] Green D, Walsh D, Mann S, Oreffo ROC. The potential of biomimesis in bone tissue engineering: lessons from the design and synthesis of invertebrate skeletons. Bone 2002;30:810-5.

[13] Atlan G, Balmain N, Berland S, Vidal B, Lopez E. Reconstruction of human maxillary defects with nacre powder: histological evidence for bone regeneration. $\mathrm{Cr}$ Acad Sci III-Vie 1997;320:253-8.

[14] Zaremba CM, Morse DE, Mann S, Hansma PK, Stucky GD. Aragonite-hydroxyapatite conversion in gastropod (abalone) nacre. Chem Mater 1998;10:3813-24.

[15] Rho JY, Kuhn-Spearing L, Zioupos P. Mechanical properties and the hierarchical structure of bone. Med Eng Phys 1998;20:92-102.

[16] Weiner S, Wagner HD. The material bone: structure mechanical function relations. Annu Rev Mater Sci 1998;28:271-98.

[17] Robinson RA. An electron-microscopic study of the crystalline inorganic component of bone and its relationship to the organic matrix. J Bone Joint Surg A 1952;34:389.

[18] Birk DE, Zycband EI, Winkelmann DA, Trelstad RL. Collagen fibrillogenesis in situ-discontinuous segmental assembly in extracellular compartments. Ann NY Acad Sci 1990;580:176-94.

[19] Jackson SF. The fine structure of developing bone in the embryonic fowl. Proc Roy Soc Lond B Bio 1957;146:270-9.

[20] Arsenault AL. Crystal-collagen relationships in calcified Turkey leg tendons visualized by selected-area dark field electronmicroscopy. Calc Tissue Int 1988;43:202-12.

[21] Kokubo T, Kushitani H, Sakka S, Kitsugi T, Yamamuro T. Solutions able to reproduce in vivo surface-structure changes in bioactive glass-ceramic A-W. J Biomed Mater Res 1990;24:72134.

[22] Mann S, Heywood BR, Rajam S, Birchall JD. Controlled crystallization of $\mathrm{CaCO}_{3}$ under stearic-acid monolayers. Nature 1988;334:692-5. 
[23] Heywood BR, Mann S. Molecular construction of oriented inorganic materials - controlled nucleation of calcite and aragonite under compressed Langmuir monolayers. Chem Mater 1994; 6:311-8.

[24] Addadi L, Moradian J, Shay E, Maroudas NG, Weiner S. A chemical-model for the cooperation of sulfates and carboxylates in calcite crystal nucleation-relevance to biomineralization. Proc Natl Acad Sci USA 1987;84:2732-6.

[25] Belcher AM, Wu XH, Christensen RJ, Hansma PK, Stucky GD, Morse DE. Control of crystal phase switching and orientation by soluble mollusc-shell proteins. Nature 1996;381:56-8.

[26] Simkiss K, Wilbur KM. Biomineralization. Cell biology and mineral deposition. San Diego: Academic Press; 1989.

[27] Sarikaya M. Biomimetics: materials fabrication through biology. Proc Natl Acad Sci USA 1999;96:14183-5.

[28] Whitesides GM, Grzybowski B. Self-assembly at all scales. Science 2002;295:2418-21.

[29] Boncheva M, Gracias DH, Jacobs HO, Whitesides GM. Biomimetic self-assembly of a functional asymmetrical electronic device. Proc Natl Acad Sci USA 2002;99:4937-40.

[30] Aizenberg J, Muller DA, Grazul JL, Hamann DR. Direct fabrication of large micropatterned single crystals. Science 2003;299:1205-8.

[31] Yeni YN, Norman TL. Calculation of porosity and osteonal cement line effects on the effective fracture toughness of cortical bone in longitudinal crack growth. J Biomed Mater Res 2000;51:504-9.

[32] Ayers RA, Simske SJ, Bateman TA, Petkus A, Sachdeva RLC, Gyunter VE. Effect of nitinol implant porosity on cranial bone ingrowth and apposition after 6 weeks. J Biomed Mater Res 1999;45:42-7.

[33] Kujala S, Ryhanen J, Danilov A, Tuukkanen J. Effect of porosity on the osteointegration and bone ingrowth of a weightbearing nickel-titanium bone graft substitute. Biomaterials 2003;24:4691-7.

[34] Midy V, Dard M, Hollande E. Evaluation of the effect of three calcium phosphate powders on osteoblast cells. J Mater SciMater M 2001;12:259-65.

[35] Heymann D, Guicheux J, Rousselle AV. Ultrastructural evidence in vitro of osteoclast-induced degradation of calcium phosphate ceramic by simultaneous resorption and phagocytosis mechanisms. Histol Histopathol 2001;16:37-44.

[36] Suzuki T, Ohashi R, Yokogawa Y, Nishizawa K, Nagata F, Kawamoto $\mathrm{Y}$, et al. Initial anchoring and proliferation of fibroblast L-929 cells on unstable surface of calcium phosphate ceramics. J Biosci Bioeng 1999:87:320-7.

[37] Shirakata Y, Oda S, Kinoshita A, Kikuchi S, Tsuchioka H, Ishikawa I. Histocompatible healing of periodontal defects after application of an injectable calcium phosphate bone cement. A preliminary study in dogs. J Periodontol 2002; 73:1043-53.

[38] Ducheyne P, Qiu Q. Bioactive ceramics: the effect of surface reactivity on bone formation and bone cell function. Biomaterials 1999;20:2287-303.

[39] Kanazawa T. General background on phosphate materials. Amsterdam: Elsevier; 1989.

[40] Mcnamara BP, Toni A, Tayor D. Effects of implant material properties and implant-bone bonding on stress shielding in cementless total hip-arthroplasty. Adv Eng Mater 1995;991:309-14.

[41] Gomez J, Rodriguez MA, Banos V, Martinez L, Claver MA, Ruiz J, et al. Orthopedic implant infection: prognostic factors and influence of long-term antibiotic treatment on evolution. Prospective study, 1992-1999. Enferm Infec Micr Cl 2003; 21:232-6.

[42] Thomas KA. Hydroxyapatite coatings. Orthopedics 1994; 17:267-78
[43] Greenspan DC. Bioactive ceramic implant materials. Curr Opin Solid St M 1999;4:389-93.

[44] Hench LL, Wilson J. Surface-active biomaterials. Science 1984;226:630-6.

[45] de Bruijn JD, van den Brink I, Mendes S, Dekker R, Bovell YP, van Blitterswijk CA. Bone induction by implants coated with cultures osteogenic bone marrow cells. Advents Dental Res 1999;13:74.

[46] Tanahashi M, Matsuda T. Surface functional group dependence on apatite formation on self-assembled monolayers in a simulated body fluid. J Biomed Mater Res 1997;34:305-15.

[47] ter Brugge PJ, Wolke JGC, Jansen JA. Effect of calcium phosphate coating crystallinity and implant surface roughness on differentiation of rat bone marrow cells. J Biomed Mater Res 2002;60:70-8.

[48] Liu Y, Hunziker EB, Randall NX, de Groot K, Layrolle P. Proteins incorporated into biomimetically prepared calcium phosphate coatings modulate their mechanical strength and dissolution rate. Biomaterials 2003;24:65-70.

[49] Wen HB, Moradian-Oldak J. Modification of calcium-phosphate coatings on titanium by recombinant amelogenin. J Biomed Mater Res A 2003;64A:483-90.

[50] Leonor IB, Azevedo HS, Alves CM, Reis RL. Effects of the incorporation of proteins and active enzymes on biomimetic calcium-phosphate coatings. Key Eng Mater 2003;240-2:97-100.

[51] Oliveira AL, Alves CM, Reis RL. Cell adhesion and proliferation on biomimetic calcium-phosphate coatings produced by a sodium silicate gel methodology. J Mater Sci-Mater M 2002;13:1181-8.

[52] Kohn DH. Metals in medical applications. Curr Opin Solid St M 1998;3:309-16.

[53] Weng J, Liu Q, Wolke JGC, Zhang XD, de Groot K. Formation and characteristics of the apatite layer on plasma-sprayed hydroxyapatite coatings in simulated body fluid. Biomaterials 1997; 18:1027-35.

[54] Zheng XB, Huang MH, Ding CX. Bond strength of plasmasprayed hydroxyapatite/Ti composite coatings. Biomaterials 2000;21:841-9.

[55] Gledhill HC, Turner IG, Doyle C. In vitro dissolution behaviour of two morphologically different thermally sprayed hydroxyapatite coatings. Biomaterials 2001;22:695-700.

[56] Fazan F, Marquis PM. Dissolution behavior of plasma-sprayed hydroxyapatite coatings. J Mater Sci-Mater M 2000;11:787-92.

[57] Yamashita K, Arashi T, Kitagaki K, Yamada S, Umegaki T, Ogawa K. Preparation of apatite thin-films through Rf-sputtering from calcium-phosphate glasses. J Am Ceram Soc 1994;77:2401-7.

[58] Burke EM, Haman JD, Weimer JJ, Cheney AB, Rigsbee JM, Lucas LC. Influence of coating strain on calcium phosphate thinfilm dissolution. J Biomed Mater Res 2001;57:41-7.

[59] Wang CX, Chen ZQ, Wang M, Liu ZY, Wang PL, Zheng SX. Functionally graded calcium phosphate coatings produced by ion beam sputtering/mixing deposition. Biomaterials 2001; 22:1619-26.

[60] Kim CS, Ducheyne P. Compositional variations in the surface and interface of calcium-phosphate ceramic coatings on Ti and Ti-6Al-4V due to sintering and immersion. Biomaterials 1991;12:461-9.

[61] Hamdi M, Hakamata S, Ektessabi AM. Coating of hydroxyapatite thin film by simultaneous vapor deposition. Thin Solid Films 2000;377:484-9.

[62] Hamdi M, Ide-Ektessabi A. Preparation of hydroxyapatite layer by ion beam assisted simultaneous vapor deposition. Surf Coat Technol 2003;163:362-7.

[63] Li P, Ohtsuki C, Kokubo T, Nakanishi K, Soga N, de Groot K. The role of hydrated silica, titania, and alumina in inducing apatite on implants. J Biomed Mater Res 1994;28:7-15. 
[64] Li P, Ohtsuki C, Kokubo T, Nakanishi K, Soga N, Nakamura T, et al. Effects of ions in aqueous media on hydroxyapatite induction by silica gel and its relevance to bioactivity of bioactive glasses and glass-ceramics. J Appl Biomater 1993;4:221-9.

[65] Peltola T, Patsi M, Rahiala H, Kangasniemi I, Yli-Urpo A. Calcium phosphate induction by sol-gel-derived titania coatings on titanium substrates in vitro. J Biomed Mater Res 1998;41:504-10.

[66] Hanawa T, Ukai H, Murakami K, Asaoka K. Structure of surface-modified layers of calcium-ion-implanted Ti-6Al-4V and Ti-56Ni. Mater Trans JIM 1995;36:438-44.

[67] Mayor B, Arias J, Chiussi S, Garcia F, Pou J, Fong BL, et al. Calcium phosphate coatings grown at different substrate temperatures by pulsed ArF-laser deposition. Thin Solid Films 1998;317:363-6.

[68] Fernandez-Pradas JM, Cleries L, Martinez E, Sardin G, Esteve J, Morenza JL. Calcium phosphate coatings deposited by laser ablation at $355 \mathrm{~nm}$ under different substrate temperatures and water vapour pressures. Appl Phys A-Mater 2000;71:37-42.

[69] Fernandez-Pradas JM, Sardin G, Cleries L, Serra P, Ferrater C, Morenza JL. Deposition of hydroxyapatite thin films by excimer laser ablation. Thin Solid Films 1998;317:393-6.

[70] Lusquinos F, Pou J, Arias JL, Larosi M, de Carlos A, Leon B, et al. Laser surface cladding: a new promising technique to produce calcium phosphate coatings. Bioceramics 14 2002;2182:187-90.

[71] Zhitomirsky I. Electrophoretic hydroxyapatite coatings and fibers. Mater Lett 2000;42:262-71.

[72] Chen JS, Juang HY, Hon MH. Calcium phosphate coating on titanium substrate by a modified electrocrystallization process. J Mater Sci-Mater M 1998;9:297-300.

[73] Shirkhanzadeh M. Calcium-phosphate coatings prepared by electrocrystallization from aqueous-electrolytes. J Mater SciMater M 1995;6:90-3.

[74] Ishizawa H, Ogino M. Hydrothermal precipitation of hydroxyapatite on anodic titanium oxide films containing $\mathrm{Ca}$ and $\mathrm{P}$. J Mater Sci 1999;34:5893-8.

[75] Leonor IB, Reis RL. An innovative auto-catalytic deposition route to produce calcium-phosphate coatings on polymeric biomaterials. J Mater Sci-Mater M 2003;14:435-41.

[76] Rey C. Calcium phosphate biomaterials and bone mineral. Differences in composition, structures and properties. Biomaterials 1990;11:13

[77] Tanahashi M, Yao T, Kokubo T, Minoda M, Miyamoto T, Nakamura T, et al. Apatite coating on organic polymers by a biomimetic process. J Am Ceram Soc 1994;77:2805-8.

[78] Oliveira AL, Elvira C, Vásquez B, San Roman J, Reis RL. Surface modifications tailors the characteristics of biomimetic coatings nucleated on starch based polymers. J Mater Sci: Mater Med 1999;10:827.

[79] Habibovic P, Barrere F, van Blitterswijk CA, de Groot K, Layrolle P. Biomimetic hydroxyapatite coating on metal implants. J Am Ceram Soc 2002;85:517-22.

[80] Li F, Feng QL, Cui FZ, Li HD, Schubert H. A simple biomimetic method for calcium phosphate coating. Surf Coat Technol 2002;154:88-93.

[81] Abe Y, Kokubo T, Yamamuro T. Apatite coating on ceramics, metals and polymers utilizing a biological process. J Mater SciMater M 1990;1:233-8.

[82] Miyaji F, Kim HM, Handa S, Kokubo T, Nakamura T. Bonelike apatite coating on organic polymers. Novel nucleation process using sodium silicate solution. Biomaterials 1999;20:913-9.

[83] Taguchi T, Muraoka Y, Matsuyama H, Kishida A, Akashi M. Apatite coating on hydrophilic polymer-grafted poly (ethylene) films using an alternate soaking process. Biomaterials 2001; 22:53-8.

[84] Oliveira AL, Malafaya PB, Reis RL. Sodium silicate gel as a precursor for the in vitro nucleation and growth of a bone-like apatite coating in compact and porous polymeric structures. Biomaterials 2003;24:2575-84.

[85] Kim HM, Uenoyama M, Kokubo T, Minoda M, Miyamoto T, Nakamura T. Biomimetic apatite formation on polyethylene photografted with vinyltrimethoxysilane and hydrolyzed. Biomaterials 2001;22:2489-94.

[86] Oyane A, Kawashita M, Kokubo T, Minoda M, Miyamoto T, Nakamura T. Bonelike apatite formation on ethylene-vinyl alcohol copolymer modified with a silane coupling agent and titania solution. J Ceram Soc Jpn 2002;110:248-54.

[87] Oyane A, Kawashita M, Nakanishi K, Kokubo T, Minoda M, Miyamoto $\mathrm{T}$, et al. Bonelike apatite formation on ethylenevinyl alcohol copolymer modified with silane coupling agent and calcium silicate solutions. Biomaterials 2003;24:172935 .

[88] Takadama H, Kim HM, Kokubo T, Nakamura T. TEM-EDX study of mechanism of bonelike apatite formation on bioactive titanium metal in simulated body fluid. J Biomed Mater Res 2001;57:441-8

[89] Hata K, Kokubo T, Nakamura T, Yamamuro T. Growth of a bonelike apatite layer on a substrate by a biomimetic process. $\mathrm{J}$ Am Ceram Soc 1995;78:1049-53.

[90] Kim HM, Kishimoto K, Miyaji F, Kokubo T, Yao T, Suetsugu $\mathrm{Y}$, et al. Composition and structure of the apatite formed on PET substrates in SBF modified with various ionic activity products. J Biomed Mater Res 1999;46:228-35.

[91] Kim HM, Kishimoto K, Miyaji F, Kokubo T, Yao T, Suetsugu $\mathrm{Y}$, et al. Composition and structure of apatite formed on organic polymer in simulated body fluid with a high content of carbonate ion. J Mater Sci-Mater M 2000;11:421-6.

[92] Oyane A, Kim HM, Furuya T, Kokubo T, Miyazaki T, Nakamura T. Preparation and assessment of revised simulated body fluids. J Biomed Mater Res 2003;65A:188-95.

[93] Lin FH, Hsu YS, Lin SH, Sun JS. The effect of $\mathrm{Ca} / \mathrm{P}$ concentration and temperature of simulated body fluid on the growth of hydroxyapatite coating on alkali-treated $316 \mathrm{~L}$ stainless steel. Biomaterials 2002;23:4029-38.

[94] Barrere F, van Blitterswijk CA, de Groot K, Layrolle P. Nucleation of biomimetic Ca-P coatings on Ti6Al4V from a $\mathrm{SBF} \times 5$ solution: influence of magnesium. Biomaterials 2002; 23:2211-20.

[95] Mucalo MR, Yokogawa Y, Toriyama M, Suzuki T, Kawamoto Y, Nagata F, et al. Growth of calcium-phosphate on surfacemodified cotton. J Mater Sci-Mater M 1995;6:597-605.

[96] Kokubo T, Kim HM, Kawashita M, Nakamura T. Process of calcification on artificial materials. Z Kardiol 2001;90(Suppl 3):86-91.

[97] Huang J, DiSilvio L, Wang M, Tanner KE, Bonfield W. In vitro mechanical and biological assessment of hydroxyapatite-reinforced polyethylene composite. J Mater Sci-Mater M 1997; 8:775-9.

[98] Tretinnikov ON, Kato K, Ikada Y. In-vitro hydroxyapatite deposition onto a film surface-grafted with organophosphate polymer. J Biomed Mater Res 1994;28:1365-73.

[99] Liu X, Ding C, Wang Z. Apatite formed on the surface of plasma-sprayed wollastonite coating immersed in simulated body fluid. Biomaterials 2001;22:2007-12.

[100] Du C, Meijer GJ, van de Valk C, Haan RE, Bezemer JM, Hesseling SC, et al. Bone growth in biomimetic apatite coated porous Polyactive(R) 1000PEGT70PBT30 implants. Biomaterials 2002;23:4649-56.

[101] Yokogawa Y, Reyes JP, Mucalo MR, Toriyama M, Kawamoto Y, Suzuki T, et al. Growth of calcium phosphate on phosphorylated chitin fibres. J Mater Sci-Mater M 1997;8:407-12.

[102] Rhee SH, Tanaka J. Hydroxyapatite formation on cellulose cloth induced by citric acid. J Mater Sci-Mater M 2000;11:44952 . 
[103] Takeuchi A, Ohtsuki C, Miyazaki T, Tanaka H, Yamazaki M, Tanihara M. Deposition of bone-like apatite on silk fiber in a solution that mimics extracellular fluid. J Biomed Mater Res A 2003;65A:283-9.

[104] Kokubo T, Kim HM, Kawashita M. Novel bioactive materials with different mechanical properties. Biomaterials 2003;24:216175.

[105] Uchida M, Kim HM, Kokubo T, Fujibayashi S, Nakamura T. Structural dependence of apatite formation on titania gels in a simulated body fluid. J Biomed Mater Res 2003;64A:164-70.

[106] Reis R, Cam L, Allan PS, Bevis MJ. Mechanical behaviour of injection-moulded starch based polymers. Polym Adv Technol 1996; 7:784-90.

[107] Reis RL, Cunha AM. Characterization of two biodegradable polymers of potential application within the biomaterials field. $\mathbf{J}$ Mater Sci: Mater Med 1995;6:786-92.

[108] Reis RL, Cunha AM, Fernandes MH, Correia RN. Treatments to induce the nucleation and growth of apatite like layers onto polymeric surfaces and foams. J Mater Sci: Mater Med 1997;8:897.

[109] Malafaya PB, Elvira C, Gallardo A, San Roman J, Reis RL. Porous starch-based drug delivery systems processed by a microwave route. J Biomater Sci Polym Ed 2001;12:1227-41.

[110] Gomes ME, Ribeiro AS, Malafaya PB, Reis RL, Cunha AM. A new approach based on injection moulding to produce biodegradable starch-based polymeric scaffolds: morphology, mechanical and degradation behaviour. Biomaterials 2001;22:883-9.

[111] Gomes ME, Reis RL, Cunha AM, Blitterswijk CA, de Bruijn JD. Cytocompatibility and response of osteoblastic-like cells to starch-based polymers: effect of several additives and processing conditions. Biomaterials 2001;22:1911-7.

[112] Gomes ME, Salgado AJ, Reis RL. Bone tissue engineering using starch based scaffolds obtained by different methodologies. In: Reis RL, Cohn D, editors. NATO/ASI series. Dordercht: Kluwer Press; 2002. p. 221-49.

[113] Gomes ME, Sikavitsas VI, Behravesh E, Reis RL, Mikos Antonios G. Effect of flow perfusion on the osteogenic differentiation of bone marrow stromal cells cultured on starch based three-dimensional scaffolds. J Biomed Mater Res 2003;67A:87-95.

[114] Oliveira AL, Leonor IB, Malafaya PB, Alves CM, Azevedo HS, Reis RL. Tailoring the bioactivity of natural origin inorganicpolymeric based systems. Key Eng Mater 2003;240-2:111-42.

[115] Galliard T. Starch: properties and potential. New York: John Wiley \& Sons; 1987.

[116] Poutanen K, Forssell P. Modification of starch properties with plasticizers. Trends Polym Sci 1996;4:128-32.

[117] Andreopoulos AG, Theophanides T. Degradable plastics-a smart approach to various applications. J Elastom Plast 1994;26:308-26.

[118] Sousa RA, Reis RL, Cunha AM, Bevis MJ. Processing and properties of bone-analogue biodegradable and bioinert polymeric composites. Compos Sci Technol 2003;63:389-402.
[119] Sousa RA, Reis RL, Cunha AM, Bevis MJ. Structure and properties of hydroxylapatite reinforced starch bone-analogue composites. Bioceramics 2000;192-1:669-72.

[120] Sousa RA, Kalay G, Reis RL, Cunha AM, Bevis MJ. Injection molding of a starch/EVOH blend aimed as an alternative biomaterial for temporary applications. J Appl Polym Sci 2000;77:1303-15.

[121] Malafaya PB, Gomes ME, Salgado AJ, Reis RL. Polymer based scaffolds and carriers for bioactive agents from different natural origin materials. Adv Exp Med Biol 2003;534:201-33.

[122] Sousa RA, Oliveira AL, Reis RL, Cunha AM, Bevis MJ. Bicomposite sandwich moldings: processing, mechanical performance and bioactive behavior. J Mater Sci-Mater M 2003;14:385-97.

[123] Marques AP, Reis RL, Hunt JA. The biocompatibility of novel starch-based polymers and composites: in vitro studies. Biomaterials 2002;23:1471-8.

[124] Mendes SC, Bezemer J, Claase MB, Grijpma DW, Bellia G, Degli-Innocenti F, et al. Evaluation of two biodegradable polymeric systems as substrates for bone tissue engineering. Tissue Eng 2003;9:S91-S101.

[125] Mendes SC, Reis RL, Bovell YP, Cunha AM, van Blitterswijk CA, de Bruijn JD. Biocompatibility testing of novel starch-based materials with potential application in orthopaedic surgery: a preliminary study. Biomaterials 2001;22:2057-64.

[126] Oliveira AL, Gomes ME, Malafaya PB, Reis RL. Biomimetic coating of starch based polymeric foams produced by a calcium silicate based methodology. Key Eng Mater 2003;2402:101-4.

[127] Oliveira AL, Leonor IB, Elvira C, Azevedo MC, Pashkuleva I, Reis RL. Surface treatments and pre-calcification routes to enhance cell adhesion and proliferation. In: Reis RL, Cohn D, editors. NATO/ASI series. Drodercht: Kluwer Press; 2002.

[128] Nagano M, Nakamura T, Kokubo T, Tanahashi M, Ogawa M. Differences of bone bonding ability and degradation behaviour in vivo between amorphous calcium phosphate and highly crystalline hydroxyapatite coating. Biomaterials 1996;17:17717.

[129] Ito Y. Tissue engineering by immobilized growth factors. Mater Sci Eng C-Bio S 1998;6:267-74.

[130] Varma HK, Yokogawa Y, Espinosa FF, Kawamoto Y, Nishizawa K, Nagata F, et al. Porous calcium phosphate coating over phosphorylated chitosan film by a biomimetic method. Biomaterials 1999;20:879-84.

[131] Girija EK, Yokogawa Y, Nagata F. Bone-like apatite formation on collagen fibrils by biomimetic method. Chem Lett 2002:702-3.

[132] Du C, Klasens P, Haan RE, Bezemer J, Cui FZ, de Groot K, et al. Biomimetic calcium phosphate coatings on Polyactive(R) 1000/70/30. J Biomed Mater Res 2002;59:535-46.

[133] Yuan XY, Mak AFT, Li JL. Formation of bone-like apatite on poly(L-lactic acid) fibers by a biomimetic process. J Biomed Mater Res 2001;57:140-50. 